\title{
Women in Merchant Families, Women in Trade in Mid-19th Century Romanian Countries
}

\author{
Nicoleta Roman
}

Starting with the $17^{\text {th }}$ century, Greek merchants and, to a lesser extent, their Balkan associates became recognized in the Romanian territories by setting up trading companies in Sibiu (1636) and Brașov (1678) under the protection of the Austrian Empire. Citing local lore, Nicolae Iorga wrote that the Saxons intermediated between the Germans, representing the West, who never crossed the Carpathians, and the Turks, representing the East, who never left Bucharest. ${ }^{1}$ To the Saxon intermediaries, were added Greeks, Romanians, Serbs, Bulgarians, and Macedonians. The Treaty of Sremski Karlovici (Karlowitz) (26 January, 1699) set the boundaries between Austria and the Ottoman Empire and emphasized the importance of transit spaces such as Transylvania, favourable to the development of flourishing economic activity and of an influential social class in the region. The 18 th century brought changes in commercial policy and the newcomers gained certain rights and began to make a profit. Until that time, they were not permitted to bring their families to the Austrian Empire from territories under Turkish rule (tara turcească), were prohibited from selling products at retail prices and from having their own street shops. ${ }^{2}$ However, political events such as the treaties of Požarevac (Passarowitz) (21 July, 1718) and Küçük Kaynarca (21 July, 1774) shaped new economic exchanges among the three neighbouring empires of Austria, Russia, and Turkey. These changes marked the decline of Ottoman influence and the rise of a Russian-Austrian rivalry in Balkan trade, which, in turn, brought new challenges regarding international commerce, merchant mobility, and immigration. Thus, Russia allowed merchants, particularly Greeks who benefitted the most, to settle down in its new ports (Mariupol, Taganrog, Odessa etc.), while in the

1 Nicolae Iorga, Brașovul și românii. Scrisori și lămuriri (București: 1905), 12; Olga Cicanci, Companiile grecești din Transilvania și comerțul european în anii 1636-1746 (București: 1981), 25; Ruxandra Moașa Nazare, Sub semnul lui Hermes și al lui Pallas. Educație și societate la negustorii ortodocși din Brașov și Sibiu la sfârșitul secolului al XVIII-lea și începutul secolului al XX-lea (București: 2010), 35-37.

2 Nicolae Iorga, Brașovul și românii, 319-320. 
Austrian Empire, Maria Theresa (1717-1780) and Joseph II (1765-1790) passed legislation in 1777 and 1783 which gradually raised the interdictions against Balkan traders. When Greek merchants, as well as other merchants from the Ottoman Empire, ${ }^{3}$ became members of the commercial Greek companies in Brașov and Sibiu, they also became Austrian subjects, which granted them free trade privileges and protection. ${ }^{4}$ Saxon merchants did not approve of these measures, which were regularly disputed and reinforced.

Until the middle of the 19th century, in order to become a member of the two commercial companies mentioned above, a merchant had to meet the following requirements: to be an Ottoman subject, to have financial means for wholesale trading, to reside with his family in Brașov or Sibiu for several years, to have no estates in Ottoman lands and to be a respectable person without any judicial record. By becoming a member of such a company, the merchant automatically became a sudit ${ }^{5}$ and was granted certain privileges a local did not have. ${ }^{6}$ The Ottoman Empire itself reached an agreement with the Austrian Empire (and other Christian powers), which allowed sudit merchants to move freely in its territory and pay a one-off fee of 3 per cent merchandise tax at the customs house. ${ }^{7}$ These measures originated from an old initiative of Emperor Leopold I (1658-1705), who sought to monopolize Austrian commerce in the Balkans and the Levant, ${ }^{8}$ and lasted until after the Treaty of Edirne (1829). It is indisputable that these measures irradiated from Transylvania towards the two Romanian principalities and thus contributed to the development of a local Romanian merchant class, capable of integrating itself and the two existing posts of Sibiu and Brașov into the Balkan commercial network. Daniel Chirot's analysis on Wallachia (which also remains valid for Moldavia) shows

3 Barbara Jelavich, History of the Balkans. Eighteenth and Nineteenth Centuries, vol. I (Cambridge: 1983), 179-184; Patricia Herlihy, "Greek Merchants in Odessa in the Nineteenth Century", in Harvard Ukrainian Studies vol. 3/4, part 1 (1979-1980), 399-400, shows that in time the commercial firms owned by foreigners represented a sixth of all those founded in Russia cf. Eadem, 405.

4 Ruxandra Moașa Nazare, Sub semnul lui Hermes și al lui Pallas, 39-41.

5 A foreign subject protected by Austrian law wherever he went and who had special status and privileged fiscal treatment; from the Italian word suddito.

6 Ruxandra Moașa Nazare, Sub semnul lui Hermes și al lui Pallas, 42-43.

7 Barbara Jelavich, History of the Balkans, 180; Andrei Oțetea, Pătrunderea comerțului românesc în circuitul internațional (București: 1977) 62-67, 70-71; Documente turcești privind istoria României, vol. II (1774-1791), ed. Mustafa A. Mehmet (București: 1983), 11-12, 42; Paul Cernovodeanu, Nicolae Edroiu (eds.), Istoria Românilor, vol. vi (București: 2002), 236.

8 Ioan Moga, "Politica economică austriacă și comerțul Transilvaniei în veacul al XVIII-lea”, in Anuarul Institutului de Istorie Națională, vol. II (1936-1938), 91. 
the principality's shift from a proto-colonial economy, which dominated in the 17 th and 18th centuries, to the status of a neo-colony in the 19th and early 20 th centuries. ${ }^{9}$ According to the paradigm of Immanuel Wallerstein-for whom the peripheries were the Americas, Southeastern Europe and other territories under Russian and Ottoman control — these two last powers developed their own "world economic systems" ${ }^{10}$ Furthermore, and particularly after the Treaty of Edirne, the Turks became a periphery of the western world and, contrary to other works (especially from Romanian historiography), France was not influential in the area until the 185 os-186os. ${ }^{11}$ The Austrian expansion in the Balkans deepened at the beginning of 18th century, occupying western Wallachia (Oltenia) for two decades, a region that fully experienced their administrative and absolutist measures. Șerban Papacostea's documented work on this period endorses Chirot's argument and highlights the Austrian economic interests in basic resources and their initiative to control commercial activities through the newly established Bulgarian and Greek commercial companies. ${ }^{12}$ They did not last as long as their counterparts in Brașov and Sibiu, but are another indication that the Balkan merchants were encouraged to expand their activities towards the Austrian Empire. The Romanians were part of this displacement, slowly emerging from their isolation via an economy based on handicraft and exports to the Ottomans. ${ }^{13}$

In this context, the number of foreigners belonging to the Balkan merchant class was on the rise, while the absorption of foreigners through kinship with Transylvanians, Saxons, and Germans slowed down at the beginning of the 19th century. The Romanian merchant migration to and from Transylvania was always in flux depending on the political stability of the region. ${ }^{14}$ This phenomenon coincided with an increase in the number of products made in Transylvania (mărfuri brașovene from Brașov and mărfuri săsești from Saxon towns and villages) which were then exported to countries in the Ottoman Empire such as the neighbouring principality, Wallachia. Dowry chests,

9 Daniel Chirot, Social Change in a Peripheral Society. The Creation of a Balkan Colony (New York-San Francisco-London: 1976), 57-117.

$10 \quad$ Ibidem, 59-60.

11 Ibidem, 94.

12 Șerban Papacostea, Oltenia sub stăpânire austriacă (1718-1739) (București: 1998), 120-122. These Bulgarian and Greek merchants were encouraged to settle in centres such as Craiova, Râmnic and Ocna.

13 For further information about exports and the development of Romanian Danubian and Black Sea ports see the works of Constantin Ardeleanu and the results of the Black Sea Research Project https://blacksea.gr.

14 Paul Cernovodeanu, Nicolae Edroiu (coord.), Istoria Românilor, vol. vi, 80. 


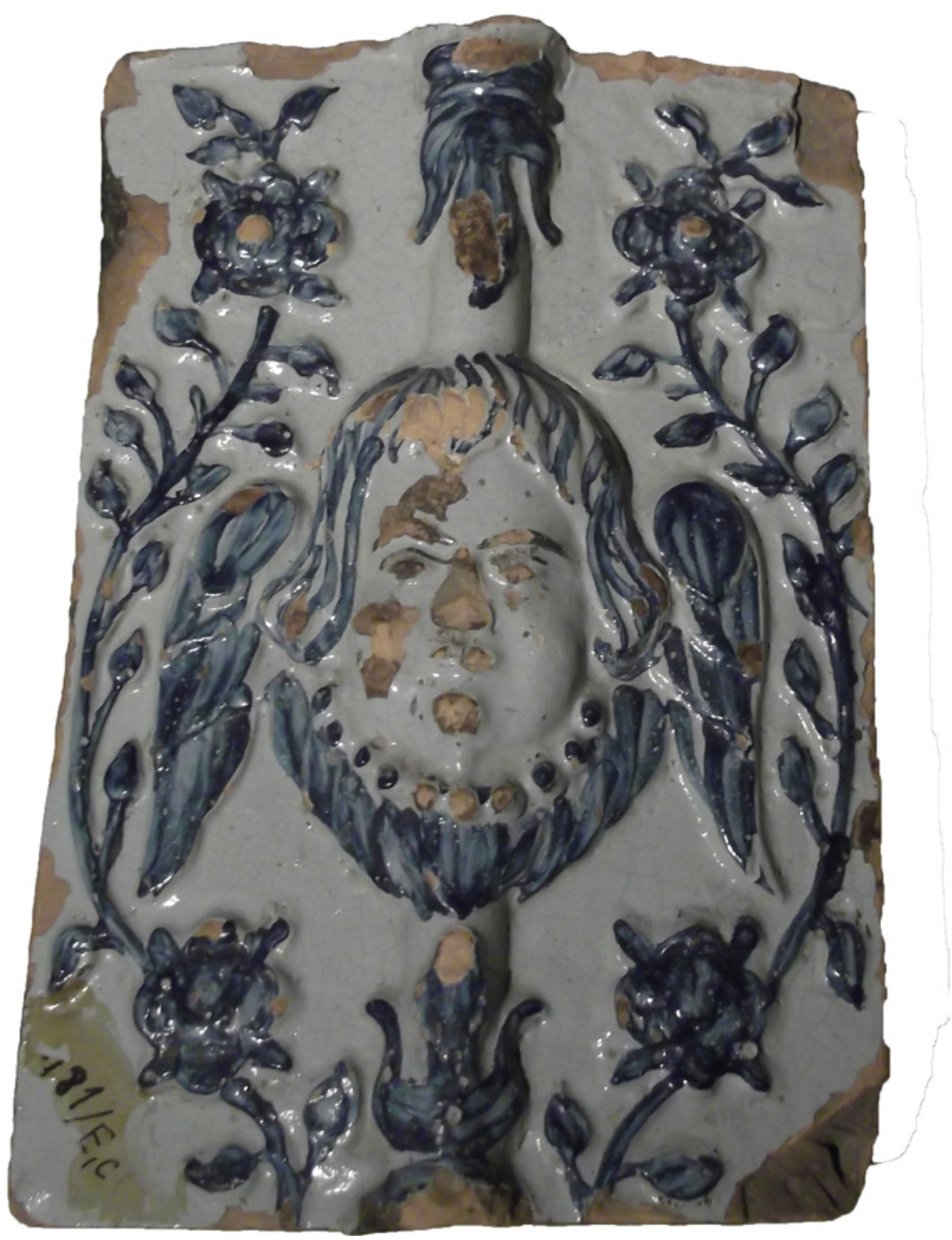

FIGURE 7.1 “Gyór" faience of Habana inspiration (cahle habane), 18th century. COURTESY OF URBAN CIVILIZATION MUSEUM, BRAȘOV.

furniture, painted stoves, Habana-inspired "Győr" faience, china, and textiles became ordinary goods in Romanian society, goods that were transmitted further on as the Balkan Orthodox merchants dominated the trade routes in both the Austrian and Ottoman Empires. [Fig. 7.1.] 
In these circumstances of political, economic and social upheaval, the problem that we raise concerns the role of women in the Romanian trade between Transylvania and the principalities of Wallachia and Moldavia. Due to a variety of political and economic factors, their presence could not be as dominant or influential as in other parts of Europe. In 18th-century Russia, wealthy noblewomen represented almost 40 per cent of economically active individuals and by 1814 , constituted a total of 4.4 per cent of the proprietors of industrial enterprises, a number that would grow in time. ${ }^{15}$ In the German cities of Stralsund and Lübeck or Scandinavian cities such as Gothenburg and Oslo, women represented around 11 per cent of merchants, with variations linked to political change. ${ }^{16}$ For the Romanian principalities, there were no favourable, stable socio-economic conditions to support such a presence. Besides living in Ottoman provinces, the local bourgeoisie was in its incipient stage ${ }^{17}$ and the state did not have an industry where elites could operate and introduce monopoly into certain branches. Furthermore, legislation to encourage commercial activity was still lacking and the very image of the merchantgenerally associated with privileged foreigners - was negative. Even so, women had an economic presence, but as silent contributors due to a domestic ideology that kept them in obscurity. Female heads of households were common to all social strata and women had their own survival strategies, family cooperation being the most commonly used. ${ }^{18}$ Our analysis explores women's emergence as visible economic agents in Romanian trade, stemming from their family background. Two issues will be under discussion: first, women's role in merchant family strategies and, second, their initiation into trade and economic activities. Our hypothesis is that, due to an unstable political and economic environment which favoured Balkan trade, women emerged as merchants and entrepreneurs from their positions as temporary substitutes for men travelling away on business.

\footnotetext{
15 Galina Ulianova, Female Entrepreneurs in Nineteenth-Century Russia (London: 2009), 2, 31, 54 .

16 Daniel A. Rabuzzi, "Women as Merchants in Eighteenth-Century Northern Germany: The Case of Stralsund, 1750-1830" in Central European History, 28, 4 (1995), 437-438, 441, notes 19 and 20.

17 Alexandru-Florin Platon, Geneza burgheziei în Principatele Române (a doua jumătate a secolului al XVIII-lea — prima jumătate a secolului al XIX-lea): preliminariile unei istorii (Iași: 1997).

18 Beatrice Moring, "Introduction", in Female Economic Strategies in the Modern World (London: 2012), 2-9.
} 


\section{The Woman in Merchant Families. The Merchant's Daughter: Seen, Liked, Married}

In the case of merchants' daughters, marriages followed the same rules as for any other young woman: courtship, dowry contract, and the wedding ceremony. However, the conditions whereby a young man could gain entry into the family and the content of the dowry differed. ${ }^{19}$ Dowries included not only precious luxury items, but also stalls, inns, shops or stock-in-hand and merchandise. For instance, Rudolf Orghidan, one of the most influential merchants in 19thcentury Brașov, married Ana, the daughter of Alexe Hagi Petkoglu, a Wallachian merchant, whose dowry gift was a shop on Lipscani Street, in downtown Bucharest. Another example is Niculae Kiriloff, a wealthy Romanian merchant from Bessarabia, who settled down in the Wallachian capital and specialized in trading Russian furriery. His daughter, Iulia, received as dowry for her marriage with his former apprentice, Luca Lucasevici, the entire merchandise from Kiriloff's main shop, which the groom used to open his new business in the city centre, on Mogoșoaia Bridge (Podul Mogoșoaiei).$^{20}$ Thus, kinship ties included establishing a territory of action ${ }^{21}$ that enabled geographical control of "the flow of goods, capital and information through trusted channels", ${ }^{22}$ and created patterns of social mobility. ${ }^{23}$

When contracting a marriage, the active group of merchants of Balkan origin living in Brașov (Romanians, Armenians, Greeks, Serbs etc.) followed certain rules. These were similar to the Austrian regulations that foreigners needed to meet in order to join the ranks of the privileged merchants of the Brașov Commercial Company. Thus, the suitor to a merchant's daughter's hand had to be a foreigner from the same social background or a known and agreedupon person. Whatever the choice, the young man had to be a business partner of one of the men in the family and, following a detailed examination of

19 Constanța Vintilă-Ghițulescu, În șalvari și cu ișlic: biserică, sexualitate, căsătorie și divorț în Țara Românească a secolului al XVIII-lea (București: 2011), 148-183.

20 Nicolae Angelescu, Negustorii de odinioară (București: 1931), 4-5, 12. This is not a bridge, but a wooden paved main road, which became the main avenue of the city by the 2oth century.

21 Gheorghe Lazăr, Les marchands en Valachie (XVII ${ }^{e}-X V I I I^{e}$ siècles) (București: 2006), 172-174.

22 Maartje van Gelder, Trading Places. The Netherlandish Merchants in Early Modern Venice (Leiden-Boston: 2009), 113 .

23 Susan Migden Socolow, The Merchants of Buenos Aires, 1778-1810. Family and Commerce (Cambridge-London-New York, 1978), 34. 
his past, must be deemed respectable. Even when love or desire played a role in the relationship, the parents still had ultimate control over who was chosen.

For example, Antonie Leca, a young merchant at the start of his career, could not marry the girl he loved, Uțica, daughter of Boguci, despite their mutual feelings for one another. In 1799, after six years of courtship, he went to ask Uțica's parents for her hand in marriage. His request was brutally refused and he was told that he was not a suitable match for her. In his disappointment, he started frequenting pubs and considered resorting to witchcraft, particularly towards the end of Uțica's engagement to another man. He even approached Chiva, an eighty-year-old woman, but she would not help him:

a young man named Antonie Leca, of German origins, started to tell me, a poor old woman, that he had been seeing for six years a young lady, Uțica, the daughter of the late Boguci, and that he would have liked to propose to her if her parents hadn't forced her to become engaged to another man. Therefore, burdened by the love he was feeling for her, he would have done something to her, something that brought about her death. I have also overheard these words from other people. But they asked me if I happened to know any woman able to undo black magic as he was thinking that somebody had done it to him. As I am serving God, I assured him I did not know any woman capable of this. ${ }^{24}$

Antonie also sent Uțica love letters, which were intercepted by her parents. When the relationship became public and Uțica died unexpectedly, Leca was considered the prime suspect. Five other men, who had also witnessed the discussion, confirmed Chiva's declaration. Moreover, the merchant Ioan Roată, from Brașov, added that the young man had been in deep despair and that his father, Răuț Leca, a trader well-known among Romanians, had wanted him to marry a merchant's daughter. The father had hoped that either Ioan Roată or Gheorghe Pop would accept Antonie as a son-in-law, but both merchants had replied, "they won't accept such a man as a groom for their daughters". ${ }^{25}$ The remark may refer to his unsettled youth, particularly his habits, but also to the tacit knowledge of his relationship with Uțica Boguci; however, marriage to another merchant's daughter could wipe away a young man's sins and cast shame on the bride and her family. In such situations, marrying up or within the same class, even after rigorous selection, was not straightforward.

\footnotetext{
24 Direcția Județeană a Arhivelor Naționale Brașov (Hereafter DJAN Brașov), Fund Actele Magistratului, 40/1800, 9 .

25 DJAN Brașov, Actele Magistratului, 40/1800, 27.
} 
In 1825 , another young foreigner sent a love poem to the young woman with whom he had fallen in love, eventually foreseeing her refusal:

Such a precious figure

In my dreams and life

With small dark brown eyes

Sparkling like diamonds under

The black curved eyebrows. And your perfect small mouth
And if my voice is never heard

I would better ask your heart

To open widely at my short thought

And have you talk in your sweetest way.

Now I may kneel in front of you.

As my strong wish is to destroy

That makes me smile with every word Any disturbance of your peace But not the others, as they stay mute, This also brings me some relief Confronted with your spotless nature. Cause I'm your servant man. ${ }^{26}$

For the Romanian merchants from Brașov, as well as for others, a potential suitor's poetic or artistic disposition was not an important attribute when considering whether to accept him into their family. Instead, such a youth had to be familiar with merchant activitie ${ }^{27}$ and have at least some entrepreneurial skills: to be a coordinator and manager, an opportunity-seeker, an innovator in his field, a decision-maker, a risk-taker, a negotiator and a team builder. ${ }^{28}$

In studying the process by which experienced merchants vouched for a particular trade debutant so that he could marry within this social class, we can discern several specific conditions. Coming from the Romanian principalities of Moldavia and Wallachia, he could not own land or a house there and must also show proof of significant capital — the equivalent of at least 2000 florins - with no financial obligations. In essence, he was expected to have economic freedom and trade experience in order to be considered for marriage, which would enable him to establish a base in the Carpathian commercial centre. Teodor Mihailovici was one such young man who fulfilled all these criteria and married Paraschiva, Gheorghe Hagi Radu's daughter. In 1808, we

\footnotetext{
26 DJAn Brașov, Actele Magistratului, 1047/1825, annex no. 5, 13-14v.

27 Louis Bergeron "Omul de afaceri" in Michel Vovelle (ed.), Omul luminilor (Iași: 200o), 88, includes a repertory of the knowledge an aspiring merchant should have: commercial laws and regulations (measures, quantities, and currencies), foreign languages and arithmetic, geography and local customs.

28 Mark Casson and Catherine Casson, The Entrepreneur in History. From Medieval Merchant to Modern Business Leader (Basingstoke: 2013), 22-40.
} 
find him asking the town magistrate for official recognition as "a town dweller" and tax-payer. ${ }^{29} \mathrm{He}$ came voluntarily from the Ottoman Empire and at the time of his request, owned an equity capital of 3,500 florins. ${ }^{30}$ If his request were approved, he would become not only a citizen of the city and a subject of the Austrian Empire, but also a full member of the Brașov merchant community.

As early as 1801, an entire group of Romanian Saxon merchants gave evidence of how the young Ghenea Radovici had fulfilled the conditions mentioned above before he was accepted amongst them; ever since his childhood he had worked for shop owners in Bucharest, including Gheorghe Ioan, his future father-in-law and business partner. Together, the two brought merchant goods to Wallachia and the capital he had gathered was put at the disposal of his father-in-law. Later on, when working for the benefit of "the royal trade" of the Austrian Empire, he sought to become a recognized subject of the state. As this was a lengthy process, who else but his business partner and relative was better placed to support him and pay his due tax for the year? Thus, marrying a merchant's daughter became an unwritten condition for acceptance into the business fraternity and wider community, and subsequently, for obtaining fiscal status. The daughter, on the other hand, could never gain freedom within marriage since, if she were widowed, she had to go and live with her brothers and/or father and take care of their households. Moreover, she could not manage her own house's financial affairs because her inheritance was controlled by her male relatives and former trade companions of her husband. ${ }^{31}$ Thus, a woman born into a merchant family was less free than one who married into a merchant family. The daughter and the merchant's daughter-in-law existed

29 In the 18th-century Austrian Empire, merchants were mentioned in the state's ledgers as fee payers (taxaliști) and their number grew steadily from 508 families in $1765 / 1766$ to 632 families in 1785 and from 942 families in 1805 to 1220 families in 1821 . They are generically called Greeks, although they also include other nationalities such as Bulgarians, Romanians, Macedonians and others cf. Paul Cernovodeanu, Nicolae Edroiu (coord.), Istoria românilor, vol. vi, 87 .

$30 \quad$ DJAn Brașov, Actele Magistratului, no. 126/1809, 1.

31 An example that can be followed over a long period of time is Tamuș Stamu's case, the sister and daughter of the merchants who founded the Greek Stamu commercial company. They arranged her marriage and managed what remained of her dowry after the death of her husband. They also managed her fortune and expressed their opinions regarding her children's education. She remained at home, in Metsovo, but could not sell her inherited property from Wallachia, complaining continuously to her brothers about the issue and the obstacles her father made to her initiative cf. Dumitru Limona, Natalia Trandafirescu (eds.), Documente economice din arhiva Casei comerciale Ioan St. Stamu (1714-1876), vol. I (București: 1983). 


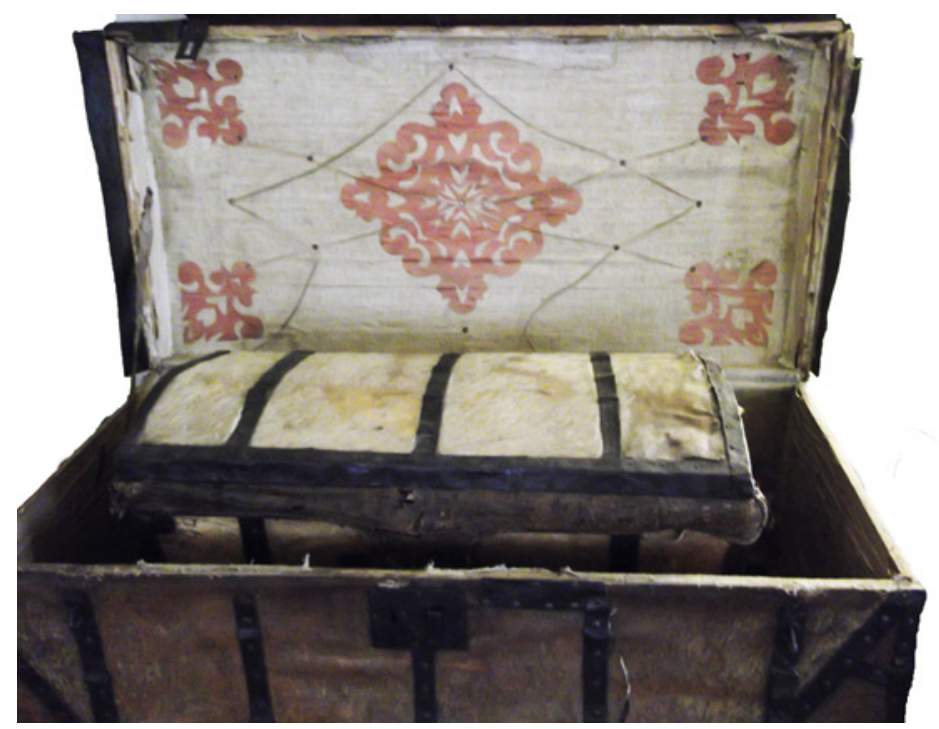

FIGURE 7.2 Travel trunks, end of 18th century-beginning of 19th century. COURTESY OF URBAN CIVILIZATION MUSEUM, BRAȘOV.

in a relationship of unequal power: the latter, being responsible only for her children, had greater opportunity to impose herself on the commercial world. [Fig. 7.2]

\section{Merchant's Daughter, Merchant's Wife}

Shortly before the wedding, daughters were provided with the most valuable goods from their father's shop, together with considerable amounts of money. The future son-in-law and the father signed the girl's dowry contract and the document entered the archive of the new family as a reference point for future discussions on the succession. Usually, after receiving her dowry, the girl lost her right to a share of her parents' inheritance, especially if there were sons yet to settle down and debts to be paid. However, wealthy merchants neither excluded their daughters from their wills nor considered their marriages as a breaking-point or the "end of responsibilities" as was the case for most brides. The girl was not a "stone in the house", ${ }^{32}$ but rather, she continued to be seen as a "good", treasured, and, if necessary, was re-invested in. Towards the latter half

32 Constanța Vintilă-Ghițulescu, "Să-mi ridic piatra de fată din casă'. Strategii matrimoniale și conflicte familiale în societatea românească (secolul al XVIII-lea)," in Sorina 
of the century, some merchant families' dowry contracts included the stipulation that the newly-weds should reside with them for a period of no more than three or four years. In 1822, for example, Simeon Nicolau from Brașov even added that if his son-in-law was willing to go to Bucharest, he would increase the dowry by 1500 lei. ${ }^{33}$ But, irrespective of the fact that Nicolau urged the young man to enter the trade world because of particular political-military events, involving potential repercussions for their family, this example emphasizes the role of the young woman in her own family. As shown in the practice of choosing her partner, the daughter of a merchant represented the instrument needed to consolidate her family's position within the same social class, ${ }^{34}$ as well as offering the possibility of controlling her new husband. Her freedom of action manifested only as far as selecting one of these possibilities, and did not extend to any choices outside the family. Elena Duzi's case best illustrates this general rule. Being the only daughter of Răuț Leca from Brașov and coming from a family where all the male members ran businesses-she was therefore expected to marry someone from the same social class. This she duly did when her parents chose the Italian merchant Marco Duzi, a business partner of her brother Dumitrache, as her future husband. However, married life proved unhappy and, on the advice of her brothers, the couple separated. When Marco Duzi went on business to Iași, in Moldavia, and with their marital problems still unresolved, Elena Duzi moved out of her house and rented a place with Dumitru Moisiu's widow. This seemed to be a good solution while she awaited her husband's return and the women agreed to rent the place for a year. However, the brothers took Elena against her will from her new home, forcing her to leave her husband in order to return to the family residence to take care of their sick father. ${ }^{35}$ After his death, her brother Ioan claimed to have restored her inheritance rights to her ${ }^{36}$ but continued to deny her any entitlement to the parental home. Following a family feud in 1824, Elena complained to the authorities that she had been beaten and humiliated by her brothers, including being stripped of her rightful inheritance. ${ }^{37}$ Despite the fact her

Paula Bolovan, Ioan Bolovan, Corneliu Pădurean (eds.), Om și societate. Studii de istoria populației României (sec. XVII-XX) (Cluj-Napoca: 2007), 95-105.

DJAN Brașov, Succesiuni, IV F 78, 685.

34 Gheorghe Lazăr, Les marchands en Valachie, 258-266.

35 DJAN Brașov, Acte Diverse, 502, 1.

36 DJAn Brașov, Acte Diverse, 500, annex no. 1, 1.

37 DJAN Brașov, Acte Diverse, 500, annex no. 1, 1. She even claimed that her brothers kept the jewellery she received as part of her dowry cf. DJAN Brașov, Acte Diverse, 502. Her husband, Marco Duzi, declared that when he learned of his father-in-law's death, he did not attend the opening of the will because he had appointed Dumitrache, his brother-in-law, as his representative and was confident in his judgement. He later learned his wife was 
father had died in 1818, six years previously, she had still not received her share. It transpired that the brothers had forged the inheritance papers and declared, in court, a less valuable fortune than the existing one. Consequently, Elena decided to return to her husband and persuaded him to help her fight for her inheritance. Setting aside their own disagreements, she gave him power of attorney to represent her in court and, from that moment on, Marco was seen speaking on her behalf, although they both signed the relevant documentation.

\section{Replacing their Husbands in Commercial Activities}

In an entirely male-dominated world, women were not at the forefront of economic activities nor did they know how to be so. However, we find women of that time buying, selling, or bargaining in their own name or on behalf of their husbands ${ }^{38}$ as in any other part of Europe. ${ }^{39}$ It is men who invest women with the economic power necessary to turn them into economic substitutes. To play this role, they had to be sufficiently involved in the family business in order to know the language of negotiation and to be able to keep registers. Coming from a merchant family allowed women to have a good start; otherwise, they had to learn everything from experience. Unlike women involved in small trade, who expressed their intentions using their thumbprint, women from merchant families knew how to keep a ledger. Despite the fact that investment in education was minimal until the end of the 18 th century, ${ }^{40}$ their schooling was sufficient to raise them above the general average. Merchants found ways to acquire knowledge useful for their trade and they valued and invested in their children's education by sending their sons to boarding schools abroad and hiring tutors for their daughters. Some merchant wives benefitted from

supposed to receive 11,289 Hungarian florins as part of the inheritance, but by declaring a lower inheritance than the real one, her brothers denied her of her rightful share cf. DJAN Brașov, Acte Diverse, 538, 1-1v.

38 George Potra (ed.), Documente privitoare la istoria orașului București, vol. I (1594-1821) (București,: 1967), 739-740; vol. II (1821-1848), 153-154, 434, 230-1; vol. III (1634-180o), 428.

39 Evguenia Davidova, Balkan Transitions to Modernity and Nation-States through the Eyes of Three Generations of Merchants (1780s-189os) (Leiden-Boston: 2013), 102; Fariba Zarinebaf, "From Mahalle (Neighborhood) to the Market and Courts: Women, Credit and Property in Eighteenth Century Istanbul", in Jutta Gisela Sperling, Shona Kelly Wray (eds.), Across the Religious Divide. Women, Property and Law in the Wider Mediterranean (ca. 1300-180o) (New York: 2010), 224.

40 Alex Drace-Francis, The Making of Modern Romanian Culture. Literacy and the Development of National Identity (London: 2006). 
the social prestige of their husbands, a prestige with religious nuances as they were called hagiica. Men gained the title (from the Turkish hadji) after a trip to the holy city of Jerusalem, ${ }^{41}$ which reinforced their influence in the merchant community. Similar to the term Kauffrau, used in German cities, hagiica was constantly utilized in public by men and their wives alike. ${ }^{42}$ It brought respectability, honour, and elevated womens' position within their class.

\section{The Woman Runs the Shop While the Husband Travels}

Women were not recognized as independent traders at that time because all their jobs were related to the domestic space and social welfare, from maids and governesses ${ }^{43}$ to aglet needlewomen. However, a merchant woman could establish herself due to the slow changes affecting trade itself, which in the 19th century was moving towards incorporating new features that eventually ushered in the modern entrepreneur. In Wallachia, the number of female weavers ${ }^{44}$ producing custom-made products and household items was considerable, while in Transylvania, Saxon cloth and aglets were also handmade and sold in large quantities by women. ${ }^{45}$ Indeed, at the beginning of the 18th century, records of discussions between merchants and the local authorities in Brassov regarding the makers of raw materials, show that for certain products there was a tradition to involve the poor, widows, and children. It was stipulated that the price offered to them should take their circumstances into account, and should not be lowered by more than two or three units. ${ }^{46}$ Luxury goods

41 Lazăr Șăineanu, Dicționar universal al limbei române ([Craiova]: 1922), 287; August Scriban, Dictionaru limbii românești (Iași: 1939), 585; Documente turcești despre istoria României, vol. II, 9-10.

42 Daniel A. Rabuzzi, "Women as Merchants", 439.

43 Nicoleta Roman, 'Deznnădăjduită muiere n-au fost ca mine.' Femei, onoare și păcat în Valahia secolului al XIX-lea (București: 2016), 191-255.

44 Eadem, 244, the 1838 census lists a total of 145 women weavers for the Wallachian town of Câmpulung.

45 In Brașov, in 1830, an aglet needlewoman who used to produce 6000 items for a price of 28 Hungarian florins per 1000 is mentioned. She was paid by Constantin Mincu, the son of a local merchant who lived in Ploiești. He also used to pay the "fat woman draper" who lived in Ulița Nouă Street, Brașov, for cloth. cf. Catalogul Documentelor Grecești din Arhivele Statului de la orașul Stalin (București: 1958), 701, 704.

46 DJAN Brașov, Actele Magistratului, 2389/1803 where it is explained that the aglet, made from a small quantity of wool was quickly sold for money. In 1819, the merchants admitted in an act that widows and poor inhabitants of Brașov manufactured white and black thick 
were mostly imports and most women were involved in a household industry, whose surplus was for sale, namely country cloth and homemade linen.

The way in which they managed the family business in the absence of men, who may be away or deceased, shows the business acumen of merchant wives. ${ }^{47}$ There are certain instances where we can get a glimpse into how the wife is trained gradually by her husband to perform commercial activities in their shop. She starts by assisting him, then takes part in conducting lowrisk transactions, and eventually has the confidence to act by herself. Thus, she trades products from her own local estate ${ }^{48}$ and buys low-value products such as food or coarse textiles for household use. Finally, when she is betteracquainted with her husband's business partners, she is ready to represent him by conducting transactions herself. Because business skills were "tied up with masculinity, men and status", ${ }^{49}$ women did not have the opportunity to pass directly from their separate, private sphere into the public domain despite having the "natural" ability ${ }^{50}$ to manage their households. In order to maintain respectability and acquire business credibility, women needed to be initiated into trade exclusively by men within their own family.

In 1806, David Lupu and his wife, Eva, conducted business jointly, and often with other merchant wives; by 1809, however, we see Eva dealing alone with large quantities of grocery products: fish, Turkish tobacco, lemon juice, caviar, oil, raisins, figs, olives and many other items. ${ }^{51}$ The wife of the rich Greek merchant Mihail T,umbru finds some business partners and trades cow leather and mackerel, turning a profit similar to her husband's: two parts share for her and one part share for her partner. ${ }^{52}$

A wife only took over her husband's entire business during periods of exceptional difficulty, on the basis of a tacit acknowledgement from members of the guild. During conflicts or military occupations, commodities were kept

twill cloth. It was also them that were used to produce small cloth accessories. cf. DJAN Brașov, Acte administrative neînregistrate, 27/1817. Hannah Barker, The Business of Women. Female Enterprise and Urban Development in Northern England, 1760-1830 (Oxford: 2006), 171.

48 DJAn Brașov, Acte Diverse, 47, 354.

49 Deborah Simonton, Women in European Culture and Society. Gender, Skill and Identity from 1700 (London-New York: 2011), 392; Béatrice Craig, Women and Business since 1500: Invisible Presences in Europe and North America? (Basingstoke: 2016), 44.

50 Deborah Simonton, Women in European Culture, 391.

51 DJAn Brașov, Acte Judecătorești, 263/1809, annex 6; Acte Judecătorești, 24/1811, annex no. 8; Acte Judecătorești, 33/1808. 
hidden locally by the most reliable merchants, regardless of gender. For instance, during the 1788 war, the border areas between the Austrian Empire and the Romanian principalities were greatly affected by the Ottoman raids. Seeking shelter in safer areas with their families, many merchants left some of their goods behind and numerous shops and warehouses were destroyed, incurring a heavy financial cost. All knew the public speculation that resulted from this kind of situation and warehouse owners were often held accountable for merchants' losses. In the justifications that ensued, several women, widows and warehouse owners provided documentation to those who trusted them. Had she testified by herself, Safta Tudoroaia from Târgu Ocna-a town in Bacău county, Moldavia - would not have been believed. So, she turned for help to other merchants and inhabitants in the town. Assisted by the priest, she testified that all the goods left in her care, including the glassware merchandise of Dumitru Lazăr from Brașov, had been burned down. The customs officer, who was cited among the witnesses, also confirmed her testimony. ${ }^{53}$ The uncertainty of commercial activities, with daily fluctuations in price, prepared women merchants to better deal with any cheating attempts. In 1813, Hagi Stoian's wife, Paraschiva, submitted testimony of transactions and prices paid for cotton purchased from various known or recommended Muslim merchants. The day after the Russian occupation of Ruse, she bought, directly from the manufacturer, eight sacks of Seres cotton at 9o paras for one oka, while a month later, she paid 115 paras for one oka. Another merchant, countryman Petru Cerniu, testified that the woman had reported the prices honestly as he had also purchased sixteen sacks at a price of 105 paras for one oka. ${ }^{54}$

Moreover, it would not be fair to regard a merchant's wife as incapable and indifferent to her husband's activities. Understanding market rules and the importance of price setting, as well as being aware of legal issues, legitimized her application to the court when fighting for justice and claiming compensation. In 1832, Zinca Titupoleos, a merchant's widow, brought Costache Fenerliu to the Court of Constantinople and accused him of fraudulent trade because the ledger had not been drawn up in accordance with "the proper procedure and the merchandising principles":

when the commodities arrived from Constantinople (Tarigrad), the day and the month are illegible, as well as the ship and the paid rent; also,

53 DJAN Brașov, Actele Magistratului, 1582/1789 and 1657/1792.

54 DJAn Brașov, Actele Magistratului, 2452/1814. 


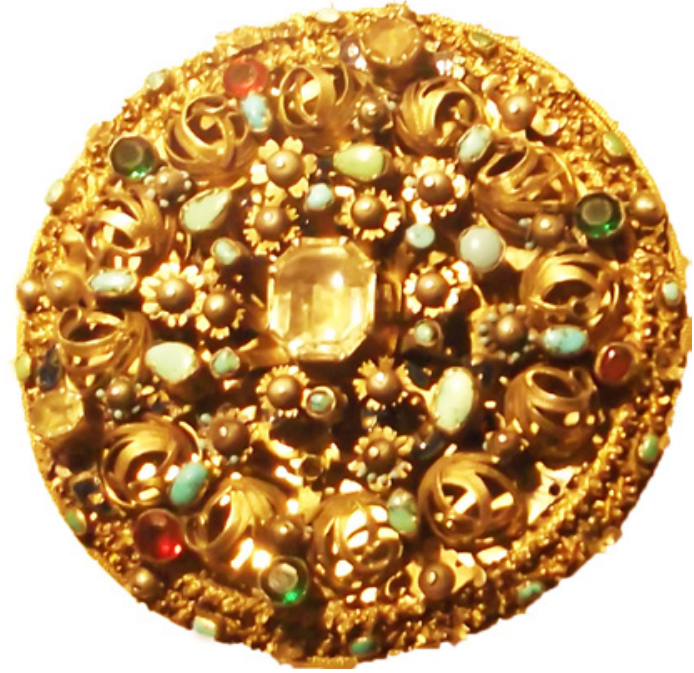

FIGURE 7.3

Women accessory made by jewellers of Brașov, 19th century. COURTESY OF URBAN CIVILIZATION MUSEUM, BRAȘOV.

there can't be seen the daily sold quantity, to whom and at what price they were sold, and to whom the most part of the goods was sold. ${ }^{55}$

The legal argument spans over four pages and shows how her husband's merchandise was transported not only to the Turkish Middle East, but also to various western ports, such as Marseille. Although a silent actor in public, Zinca knew everything about their business, proving that she was a skillful partner to her husband.

We can also observe a gradual inclusion of women in financial loan networks. In spring, 1821, and in the presence of Nicoleta, Ioan Lioliu's wife, Ioan Gima and his brothers signed an agreement to borrow from her, for the needs of their commercial association, 12,501 groși and 30 paras, which they pledged to repay at a rate of 1 per cent interest a month. ${ }^{56}$ This was obviously a case where a wife merely represented her husband in a loan agreement, but there were instances where women acted alone, as shown by Zoița Alexandroaia's case, in 1823, when she lent 3800 groși to Ioan Dimitrie Constantin Bicu and his company "for business purposes". ${ }^{57}$ [Fig. 7.3.]

55 Dumitru Z. Furnică, Din istoria comerțului la români, mai ales băcănia. Publicațiune de documente inedite: 1593-1844 (București: 1908), 379; George Potra, Documente, vol. I (15941821), 726-729.

56 Documente economice din arhiva casei comerciale Ioan St. Stamu, 1714-1876, vol. I, 112.

57 Ibidem, 132. 


\section{Merchant Widows and Business}

Even though merchant widows abided by unwritten rules, their activities were recorded tacitly in documentation of the period. Like all other women, they were obliged to give alms for their late husband's soul and mourn him for a year; however, unlike other widows, whose main responsibility was to take care of the family, merchant widows also had to take care of their late husband's business. Low social class widows could even be compensated for their contribution to the prosperity of the family by inheriting half of the fortune. Some merchants even stipulated this in their wills, such as Dumitru Pană who bequeathed half of his wealth to Maria Leca because "we both have worked together to enjoy what we have now". 58 In merchant families, wills would not only refer to the widow's economic stability but also determined the power transfer. As everywhere in Europe, proprietorship was highly linked to household leadership and the best way to acquire both family and business authority was through inheritance. ${ }^{59}$ The widow took over the business with all its assets and shortcomings until her children reached the age of consent or until the testator provided it. The inheritance always included the woman, as she became the head of the family and, after her retirement from economic life, she and her children could negotiate her share in the profits of the business, usually an amount that would grant her some comfort in life.

In the spring of 1824, Chirața Mincu from Ploiești was in dispute with her two sons, Gheorghe and Constantin, on this subject, as they refused to recognize the decision of their father, the late merchant Constantin Mincu Marinovici from Brașov (Brașoveanul). Only upon arriving in front of Teodor Mișu, the guildmaster, did the children and their mother reach an agreement. Being Austrian subjects (sudiți chesaro-crăiești), they asked the guildmaster for justice at the consulate in town. Each of the sons received one half of the store and three acres of vineyard. The rest of the vineyard, money, parental houses and two inns-one at the periphery of the city on the road to Poiana Câmpina-remained with the mother until her death. Afterwards, the brothers could share the remaining wealth between them: Gheorghe would get all the shops and Constantin all the other buildings. The daughters did not get anything since they had taken their dowry on the occasion of their marriages. Chirața Mincu ended her involvement in the businesses of Ploiești, and agreed to lend her sons the capital that she had accrued which amounted to 2,396

\footnotetext{
58 DJAN Brașov, Succesiuni, IV F 27, 820.

59 Galina Ulianova, Female Entrepreneurs in Nineteenth-Century Russia, 30; Evguenia Davidova, Balkan Transitions, 104.
} 
thalers. For the first year, the loan would be interest-free, after which her sons would be expected to pay her an annual interest rate of 5 per cent. A new contract was concluded between them ${ }^{60}$ and the verdict made the woman happy in two respects: as a merchant, she solved all the inheritance disputes she had with her sons and recovered everything she owned from the inn while as a mother she gave her children enough time to adjust to their new position. If Gheorghe were to prove to be a good administrator, he could successfully run the family-owned inns, while Constantin would take good care of her by being in charge of the household's prosperity.

A woman could be a temporary member of a company, which allowed her to represent and intervene for the man who would eventually take her place. She would be part of a fragile group by virtue of its small number, but accepted by the male community. In 1803 in Sibiu, a Greek trade company accepted Zamfirița, Teodor Mihai's widow, as a member after she took an oath to the Protector of the Faith, Emperor Francis II. Furthermore, she intervened to make her new husband, Constantin Bălan of Ioannina (Epirus), a new member of the company, arguing that they had equity and could bring new business. ${ }^{61}$ Even though her involvement was temporary, widowhood and her name paved the way for her new husband's commercial activities, which was proof of the power a woman could hold.

Having inherited her husband's authority, an authority reinforced by her sons, women of the period could remain in the same field of business, strengthening the family's prestige and good governance. This enabled them to gain a local reputation that facilitated a move towards the broadening of trade relations. The wife of Voicu Ciopală from Săcele appears constantly in the documents of the great merchant Mihail T,umbru as one of his most reliable providers, her entrepreneurial abilities exceeding those of her late husband. Continuing the business partnership, she specialized in obtaining the fine leather used in leather goods, ${ }^{62}$ overseeing customs procedures and ensuring efficient distribution to Țumbru's shops in Wallachia. The merchant's archive shows how she ran her business: her sons took care of local transportation and distribution while she established the terms and conditions of sale, and arranged payment. She was also responsible for the acquisition of

\footnotetext{
6o DJan Brașov, Succesiuni, Iv F 74, 442.

61 Dumitru Limona (ed.), Catalogul documentelor referitoare la viaţa economică a Țărilor Române în secolele XVII-XIX: documente din Arhivele Statului Sibiu, vol. I (București: 1966), 419 .

62 In the original text, they are named cordovane or sahtiane, goat or sheep skins of highquality leather, used for making luxurious shoes and accessories.
} 
complementary tannery products ${ }^{63}$ and other raw materials, including the goat thread necessary for producing footwear. Being an intermediary and a provider, she always received one part share of the profit whereas Țumbru got two. The cash or bank payments ${ }^{64}$ collected by the bank in Sibiu ${ }^{65}$ show her familiarity with, and knowledge of, financial terms and records. Women took over trade activities as well as a share of income, becoming as equal a partner as their late husband, in line with his social status. For instance, Voiculeasa Ciopală transformed herself from a subordinate position as a worker and producer of goods into a supplier, distributor, and entrepreneur. At the end of the 18th century, only a limited number of women in the Romanian business world achieved this level of success as it was not yet possible for them to become merchants without the support of men.

This transition is gradual, balanced, well-accepted and integrated into the practices of the Romanians and other merchants from Brașov where we encounter cases of wives and widows as substitutes. In Moldavia and Wallachia, in the absence of a strong local merchant class, women's business opportunities increased, but only within the limits of a model that did not challenge established trading practices in the male world. Merchant women became more and more independent due to the gradual changes affecting the profession itself during the 19th century. Thus, the emancipation and recognition of women as entrepreneurs, merchants, and professionals in other fields of activity came with the imposition of a new male standard of training and personal development as a consequence of economic liberalization and the technological and industrial revolution. In becoming factory owners, old merchants empowered women to trade goods, especially textiles and luxury products. By the end of the 19th century, women become owners of fashion houses, stores, upscale shops and even small linen factories. However, even when this new threshold was reached, gender differences continued to exist. Widows enjoyed a privileged situation among other women as they carried with them the prestige of the family and the economic success of their late spouse. This afforded them relative freedom, a spirit of initiative, and distinct economic momentum. If children were involved and expected to take over the family business, their commitment and ability to increase profits could not always be guaranteed. In 1859, Ilie Zamfirescu's trade was affected by the bankruptcy of Nicolae Hristu,

63 The word is scumpie, the skin and the leaves of this shrub were used in tannery and dyeing.

64 Banco-țidulele were small pieces of paper serving as proof of receipt. A kind of cheque.

65 Catalogul Documentelor Grecești, 251-253, 255, 258, 261, 265, 267, 271, 273. There are similar cases such as Ivănoaia Buzatu or that of the widow of Oprea Țârcă cf. Ibidem, 262. 
a banker in whom he invested a great deal of money. When he died in 1862, he left behind diminished earnings and two commercial partners in distress. His wife, Maria, took over the business as the legal guardian (tutore) of their children. She not only managed to have a good relationship with her husband's partners, but, by 1873, when her son returned from studying in Vienna, she had increased the capital. ${ }^{66}$ Another example is Alexandrina Assan, who was a merchant and an entrepreneur. Her husband, George Assan (1821-1866), had several pharmacies and wine shops from which he gained a sufficient amount of money to buy modern machinery from Vienna and construct a steam mill on the outskirts of Bucharest in 1853. After his death, Alexandrina ran the firm and the steam mill for 20 years, until their sons took over the business in 1884 . The Assan steam mill was one of the first Romanian industrial establishments, active into the 2oth century, ${ }^{67}$ and the family represents the perfect example of a gendered evolution within their social class. The husband transformed from a classical merchant to a modern entrepreneur, owner and administrator of an industrial firm heavily involved in the national economy. ${ }^{68}$ The wife became visible, ceasing to be a substitute and secondary actor, and proved herself to be as equally capable as her late husband in the same role.

\section{A Case Study: The World of Safta Castrișoaia}

In late 18th-century Brașov, part of a significant community of Balkan merchants, including Greeks, Macedonians, Bulgarians, Serbs etc., who managed to achieve status and economic influence, Gheorghe Castrișiu, a young Macedonian trader, started to make a name for himself. Coming from Greece to Bucharest in 1796, with a small, but still prosperous business, he entered a commercial partnership with brothers Elefterie and Mărgărit Ioan, and more significantly, with the experienced merchant Mihail Țumbru from Brașov. Planning to develop a transportation network, Tumbru was looking for new partners and was very content with Castrișiu whom he described as "an able and good young man"69 who put all his efforts into transporting their products. Shortly after, Castrișiu proved to be a serious merchant and extended

\footnotetext{
66 Nicolae Angelescu, Negustorii de odinioară, 8.

67 Dumitru Z. Furnică, Din istoria comerțului, 536-538; Basil G. Assan, 1853-1903: o jumătate de secol de la introducerea mașinei cu aburi în industria română de către George Assan. Conferință susținută la Societatea Geografică (București: 1904), 8.

68 Louis Bergeron, "Omul de afaceri”, 90.

69 Catalogul Documentelor Grecești, vol. I, 525.
} 
his contacts. After several years, he was able to bring high-quality products to his shop from Bucharest. For instance, banker and businessman Nicolae Hagi Moscu sent him boxes of gold cigarette cases set with diamonds and precious stones from Vienna, via Țumbru, with the help of the Austro-Hungarian stagecoach; ${ }^{70}$ Rizu Dormuși and Sons company from Budapest sent him bales of coffee, cloth, furrier's trade products and chests with muslin; ${ }^{71}$ and, Safranu and Manicati Sons company from Sibiu sent him barrels of sugar, natural dyes, and fine fabrics. ${ }^{72}$ Because he had a good reputation as a tradesman, the G. K. (Gheorghe Castrișiu) brand also accompanied any merchandise sent to the Habsburg area from 1802 onwards. ${ }^{73}$

Even though sources about his family have not yet been uncovered, we know the merchant died in Bucharest around 1810 and his Macedonian widow, Safta, inherited his entire fortune. Under his widow's management, the fortune that had built around several shops owned by Gheorghe Castrișiu in Bucharest was completely transformed. With the arrival of the Russians in Wallachia (1829), Safta declared herself subject to their rule and the business benefitted from this new status. The first census, from 1838 , shows her living in a large house in the Saint Dimitrie suburb of Bucharest. With a Jewish tailor and a Serbian innkeeper as neighbours, Safta Castrișoaia declared herself Romanian in front of the authorities who wrote down her age as $45^{74}$ and noted that she was living in the house situated at number 1680 together with her 70-year-old father-inlaw, Constantin Castrișiu. Besides three gypsy slaves (robi), she also had a large number of servants (two coachmen, three valets, three servants, two cooks and a washerwoman etc.) as well as a soldier and an Albanian (arnăut). ${ }^{75}$ The fact that an innkeeper and a barber were registered at the same house, ${ }^{76}$ as well as double the usual number of people in domestic service, denotes the existence of a tavern. Her prosperity had already been apparent and her late husband's

\footnotetext{
$70 \quad$ Ibidem, vol. I, 563, 582-3, 601.

71 DJAN Brașov, Actele Magistratului, 125/1802 and Catalogul Documentelor Grecești, vol. I, 583-4.

72 Catalogul Documentelor Grecești, vol. I, 94, 534, 556, 592.

73 Catalogul Documentelor Grecești, vol. I, 604.

74 Her birth year, 1782 , is mentioned on the upper side of her anonymous portrait, which means she was 11 years older than the age recorded by the census taker.

75 The term makes a reference to mercenary soldiers of Balkan origin employed as personal guards. Associated first with Albanians, this is a generic term including Greeks and Serbs.

76 Arhivele Naționale Istorice Centrale (Hereafter ANIC), Fund Catagrafii, I-82, 366.
} 
elder brother, Constantin Castrișiu, had also settled down in Bucharest and become a copyist, thus occupying the last boyar rank. ${ }^{77}$

During the Organic Regulation period, Safta's reputation as a female merchant was already consolidated and she became a great owner and philanthropist. While initially benefitting from the protection of her husband's name, she later made herself visible and by $185^{\circ}$, few still remembered him while everyone knew her. She owned numerous properties and all her trade shops were located in the central area of Bucharest. In 1826, when she needed to expand, she bought several shops in Zamfir's Inn and, in addition to those held in the Izvor quarter, she also developed an entertainment area with a terrace. The latter seems to have been a place of refuge for participants in the 1848 Wallachian revolution, being also reputed to tolerate prostitution. However, located on the Mogoșoaia Bridge - a luxury commercial avenue - the inn was her most important property. Foreign travellers, consuls, boyars and their equipages often took this road which was to become the main shopping street in the capital, often compared with the French Champs-Élysées. Safta Castrișoaia's inn did not only have a restaurant with hosting rooms, but also a space incorporating shops. Situated between the passage built by the architect Xavier Villacrosse and Doamnei Street, with one side bordering Lipscani Street, the inn was close to three other similar establishments (Câmpineanu Inn, Filipescu Inn, and Greceanu Inn), of which only one was held by a woman, Câmpineanu's widow. ${ }^{78}$

In fact, the entire area was cosmopolitan and some parts of adjoining properties held by Safta Castrișoaia displayed a strong Macedonian imprint. Two other rich Macedonians lived nearby, one of whom was called Petrovici-Armis. By the end of the 19th century, he kept an Albanian guard in front of his house, wearing a kilt, a fez hat, and guns at his girdle. ${ }^{79}$ In this way, the whole urban community tacitly agreed to present an ethnic identity within a commercial zone that was highly frequented in Bucharest. Just like all merchant families, the Castrisiius wished to create a dynasty to rival some of their acquaintances. But destiny had been unkind to them. Son Dimitrie died young, at only 31 years of age, and the epitaph on his grave in the yard of the Saint Dimitrie Church of Bucharest shows the aspirations that his mother, the widow Castrișoaia, nurtured for him:

77 Paul Cernovodeanu, Irina Gavrilă, Arhondologiile Țării Românești de la 1837 (Brăila: 2002), 72. The conțepist rank is part of the last category, the 9th one, making up the boyar ranks in the Romanian region. Constantin Castrișiu (or Castriș), acquired this rank in 1856 .

78 Gh. Crutzescu, Podul Mogoșoaiei: povestea unei străzi (București: 1986), 104.

79 Ibidem, 110. 
In my youth when happiness was above everything, And everything seemed to be so promissing, I used to be the pillar of my family, my mother's sense of gratitude But the cruel razor cut this pillar that blew away the flame of hope In front of which my mother's tears are quietly pale. ${ }^{80}$

Without doubt, Dimitrie's death led to Safta Castrișoaia's subsequent focus on her philanthropic activities. Fragments of the widow Castrișoaia's will, lost today, were incorporated into the correspondence exchanged between the legal guardians (epitropi) after her death in 1862. These extracts reveal to us her intentions regarding her own carefully maintained wealth. The terrace from the Izvor quarter had been sold as early as $185^{\circ}$ to William Oppler, who built one of the most notorious breweries of the Romanian Old Kingdom there, incorporating, next to the terrace, a restaurant and small entertainment theatre. ${ }^{81}$ Six shops and a coffee house remained under her management, but, over the years, due to her age, Safta Castrișoaia opted to rent them out. Similarly, the five estates-Grosu, Măgura, Plosca, Gurueni and Călinești-were leased out. ${ }^{82}$ It seems that she was particularly fond of the one in Măgura, Teleorman county, as she decided to build a church there in $1846 .{ }^{83}$ As she didn't have any children, she arranged that her nephew, Vasile Paapa (1819-1884), should inherit half of her fortune, the other half being given away, with conditions attached, to the state. The rural churches and schools were to remain in Paapa's care to be repaired and maintained. The guardianship (Epitropia), instituted by the state to administer her fortune, was intended to pay off her debts to her relatives, ${ }^{84}$ after which it was to be used, through the managements of assets, to support the following causes: a student in Paris; seven hermitages and the priests from the Saint Dimitrie Church in Bucharest, where her son was buried; local hospitals; a girl's dowry; and, not least, annual Easter and Christmas donations to the poor. ${ }^{85}$ The will included the caveat that the benefits granted to the

$80 \quad$ Ibidem, 74; Gheorghe Bezviconi, Necropola Capitalei (București: 1972), 87.

81 Hans Kraus, L. Bachelin, Bucarest et la Roumanie (Bucharest: 1902), 165.

82 ANIC, Fund Safta Castrișoaia, 4/1868.

83 Gheorghe I. Lahovari, Marele Dicționar Geografic al României, vol. 2 (București: 1899), 49.

84 ANIC, Fund Safta Castrișoaia, 3/1862, 2v. The debts were to be paid to her sister-in-law; nieces and nephews from her husband's side; and her brother-in-law's children, numbering five girls and one boy. Three of the nieces had come to Bucharest, two were in Salonic, while the elder boy had left for Alexandria, Egypt.

85 ANIC, Fund Safta Castrișoaia, 3/1862, 4V.-5; 4/1868, 63. 
poor should give priority to all those who had come to know Safta Castrișoaia and receive aid from her, when she was still alive. Many of those who claimed assistance mentioned the woman's past generosity. ${ }^{86}$ As for the medical institutions, which received an annual income of 500 thalers, Filantropia Hospital in Bucharest treated ten sick patients while the hospital in Ploiești took care of six individuals. Safta Castrișoaia's gestures reflected the three philanthropic directions of Romanian society: religious, towards the churches close to the donor, education and training and, equally important, medical. At the same time, her generosity also reflected a society transitioning from pity to charitable feelings, ${ }^{87}$ undoubtedly crucial for the formation of citizenry. From 1833 onwards, the widow also sponsored Romanian national and cultural institutions through annual fixed contributions to the first national theatre. ${ }^{88}$

At the end of the 19th century, memories of the woman merchant who had acted so firmly but discreetly within the Bucharest market, and whose commercial activities had led to such philanthropic gestures, were still strong. Although the luxury trade artery of Mogoșoaia Bridge (today Calea Victoriei) had had its ups and downs, Safta Castrişoaia had been wise enough to invest in spaces that could preserve the legacy of her business. Although elegant and fashionable shops replaced the inn and pharmacies that she had run, she still remained part of the urban memory of the place. Her husband's vision also made a lasting impact by successfully bringing fine and expensive goods from European capitals and, to a lesser extent, Constantinople. Furthermore, she remained in the consciousness of the community as a philanthropist who wanted to share her prosperity with the poor. She also directed her attention towards the church, and, in the middle of the century, when modernization of society took place and education became a priority, she was among the first to devise a private economic system built around her shops and properties in order to support those in need. Her example is inspired by the activities of another widow, Safta Brâncoveanu, a famous boyar, who had laid out the legal foundation of Brâncoveanu Establishments. ${ }^{89}$ They included hospitals and schools which were subsidized by the income from her estates, surviving

86 ANIC, Fund Safta Castrișoaia, 3/1862, 4; 5/1869, 93, 98.

87 See Ligia Livadă-Cadeschi, De la milă la filantropie: instituții de asistare a săracilor din Țara Românească în secolul al XVIII-lea (București: 2001) and Nicoleta Roman, "Ancien orphelin, futur citoyen de l'État. L'abandon infantile et l'assistance sociale entre initiative privée et autorité de l'État dans la Valachie moderne", in Penser le XIX ${ }^{e}$ siècle: nouveaux chantiers de recherche, eds. Silvia Marton, Constanța Vintilă-Ghițulescu (Iași: 2013), 125-152.

88 I. Xenofon, Filarmonica de la 1833. Centenarul primei reprezentații de teatru național în București (București: 1934), 19.

89 Emil Vârtosu, Ion Vârtosu, Așezămintele Brâncovenești. O sută de ani de la înființare (18381938) (București: 1938). 
more than a century into modern times. This philanthropic direction of the merchant class that favoured schools and hospitals over religious foundations was visible by the end of 17 th century and is explained by its need for social recognition and development. ${ }^{90}$ The aspiration of merchant families was to enter into the boyars' circle, and to frequent it until, finally, they became part of it.

The portrait of Safta Castrișoaia shows the impact of western influences on her life; the detachment of widowhood, and the absence of mourning clothes. Looking directly at us, with conjoined eyebrows in keeping with old oriental fashion, she exudes a strong personality and harsh traits. While the turban and the veil are reminiscent of the Orient, the ribbons in her hair highlight a western style. The white silk gown in an empire-line style, with floral embroidery and designs, discreetly emphasizes a low neckline and the main accessories (earrings and a necklace) contain pearls, a symbol of widowhood. The hallmark ring underlines both her importance and her position as head of the family. [Fig. 7.4]

However, in spite of her business activities, posterity remembers Safta Castrișoaia as a philanthropist, an aspect she would have considered of secondary importance, her portrait including only a short posthumous foreign note regarding her donations to hospitals. She clearly had "a sense of belonging to an important stratum of society"91 and followed in the footsteps of many merchants who included symbols of their trade and specialization in their portraits. Perhaps, had she had the choice, she would have included the inn from the centre of Bucharest as a landmark of her work and as a background in her portrait. In doing so, she would have rivalled Apollonia Hirscher (?-1547), the wife of a merchant and high official from Brașov, who was the founder of the Merchants' House (Casa Negustorilor) in the Transylvanian town and who completed its commercial centre around the current main square. ${ }^{92}$

As Joseph Adalbert Krickel showed in 1827 , both locals and travellers, particularly in the 19th century, remembered the significant role Appolonia played in the Braşov trade:

A new type of building became home for me, a big house with a floor, built around 1545 by Apollonia Hirscher, the wife of a high official. Since the fire of 1809 the building no longer had glass panes. I climbed 15 steps of the stairs and I arrived at a multitude of corridors with small shops

90 Gheorghe Lazăr, "Negustori mecena în Țara Românească”, in Studii și Materiale de Istorie Medie, 2005, 160-161.

91 Lina Bernstein, "Russian Eighteenth-Century Merchant Portraits in Words and in Oil", in The Slavic and East European Journal, 3 (2005), 410.

The building now hosts one of the most celebrated restaurants: "Cerbul Carpatin". 


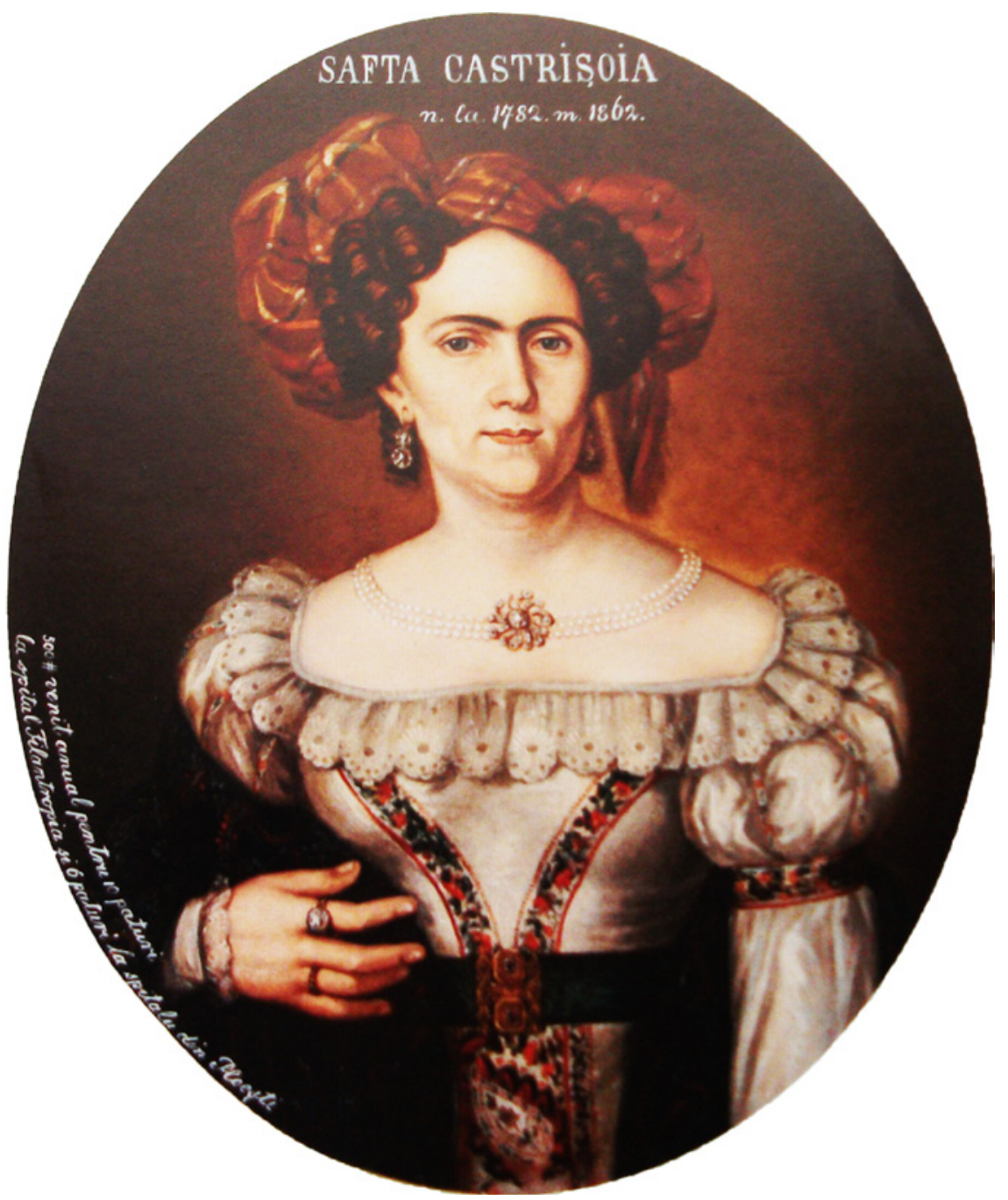

FIGURE 7.4 Safta Castrișoaia, wife of merchant Gheorghe Castrișiu, the Macedonian (Bucharest, Wallachia, around 1850-186o), in Mariana Vida, Elena Olariu, Epoca Biedermeier în Țările Române (1815-1859) (București: Editura Muzeul Național de Artă al României, 2014).

where hundreds of merchants were offering their goods for sale. This large number of people-Saxons of Transylvania, Hungarians, Armenians, Greeks, Turkish, Romanian boyars, Jews from Turkey, Gypsies-as well the bustling people, reminded me that I was in a significant trade town. In the market of the town and around the House of Commerce, I noticed 
Turkish usurers staying at a little table on which there was a little gridded box comprising rolls of Austrian and Turkish silver and golden coins. ${ }^{93}$

Both Apollonia and her husband, Lucas Hirscher, are depicted in portraits with the Merchants' House in the background and, respectively, St. Martin Church and Bran Castle, all three having benefitted from their financial support. ${ }^{94}$ The widow of Saxon origins seems to be an exception in her era and her portrait encompasses her entire desired identity, just as Safta Castrișoaia represents a Romanian counterpart on a smaller scale.

\section{Conclusion}

In the eyes of their men, women from merchant families represented a valuable human resource and a powerful social tool for attracting new family members as well as new business partners. While their daughters enjoyed domesticity, wives had to learn the skills needed to replace men in trade activities if necessary. They assisted their husbands, participated in negotiations, and proclaimed the right of representation, reception, and business management. Being a member of a merchant family came with conditions and, although, ideologically, society operated within a separate sphere, the reality was different as it entailed various social class necessities. According to Evguenia Davidova, there was a coexistence with the other more nuanced concepts of "joint" and "segmented" spheres. ${ }^{95}$ We will push the nuance even further and argue that, within the merchant and entrepreneurial group, at least for the Romanian case, widowed women were on an equal footing with men until their sons took over the business. Yet, they were still not mobile actors since they did not have the opportunity to move freely from one sphere to another as their merchant husbands did. Merchant women learned to act and manage commercial activities through men and therein lies their greatest personal and

93 Călători străini despre țările române în secolul al XIX-lea: serie nouă, vol. II, (eds.) Paul Cernovodeanu, Daniela Bușă, (București: 2005), 225. There is a similar paragraph in Adolf Schmidl in 1835, in Călători străini, vol. III, 300.

94 Apolonia des Kroner Richters Lucas Hirscher / Wittwe Stifterin dieses Zunftgebäudes. / das Originalgemählde befindet sich auf dem Rathause in Cronstadts (Apolonia, widow of the high official, Lucas Hirscher, the founder of the Guild House, original painting found in Casa Sfatului of Brașov according to note 7 of Radu Popica, "Portretele patriciatului săsesc din Brașov. Un capitol de arta transilvană”, in Portretele Patriciatului Săsesc din Brașov. Un Capitol de Artă Transilvană. Catalog (Brașov: 2013), 13.

95 Evguenia Davidova, Balkan Transitions, 128. 
public achievement. At that time, they were at the periphery of Balkan economical activities in the same way that the Balkans were perceived to be at the periphery of civilized Europe. Their situation progressed slowly following the influence of western ideas, movements and the examples of women travellers, explorers and feminists; some of whom came to the Romanian territories. To assess the two centuries which followed, further research is needed to explore women's presence in the economy as more active traders and their utility for the industrial sector. Access to state and, sometimes, private education paved the way for women to achieve these objectives.

\section{Bibliography}

\section{Archival Materials}

Arhivele Naționale Istorice Centrale [National Archives. Main Headquarters].

Direcția Județeană a Arhivelor Naționale Brașov [National Archives. Brașov County].

Funds Acte Administrative neînregistrate, Acte Diverse, Acte Judecătorești, Actele Magistratului, Succesiuni [Unregistered Administrative Papers, Various Papers, Judicial Documents, Magistrates' Papers, Successions].

Funds Catagrafii and Safta Castrișoaia [Tax Ledgers and Censuses Fund and Safta Castrișoaia's Personal Fund].

\section{Other Primary Sources}

Travel Accounts

Călători străini despre țările române în secolul al XIX-lea: serie nouă [Foreign Travellers to the Romanian Countries in the 19th century], (eds.) Paul Cernovodeanu and Daniela Bușă, Vol. I-IX (București: 2004-2015).

\section{Published Documents}

Catalogul Documentelor Grecești din Arhivele Statului de la orașul Stalin. [The Greek Documents Catalogue from State Archives] Vol. I (București: 1958).

Catalogul documentelor referitoare la viaţa economică a Țărilor Române în secolele XVII-XIX: documente din Arhivele Statului Sibiu, [The Documents Catalogue on the Romanian Principalities' Economic Life in the 17th-19th Centuries] Dumitru Limona ed. Vol. I (București: 1966).

Documente economice din arhiva casei comerciale Ioan St. Stamu, 1714-1876 [Economic Documents from the archive of Ioan St. Stamu Commercial Company], eds. Dumitru Limona, Natalia Trandafirescu. Vol. I (București: 1983).

Documente privitoare la istoria orașului București [Documents on the History of Bucharest], ed. George Potra. Vol. I (1594-1821) (București: 1967). 
Documente turcești privind istoria României [Turkish Documents About the History of Romania], ed. Mustafa A. Mehmet. vol. II (1774-1791) (București: 1983).

\section{Secondary Sources}

Assan, Basil G., 1853-1903: o jumătate de secol de la introducerea mașinei cu aburi în industria română de către George Assan. Conferință susținută la Societatea Geografică [1853-1903: Half a Century Since the Introduction of Steam Machinery to Romanian Industry by George Assan. Conference held at the Geographical Society] (București: 1904).

Barker, Hannah, The Business of Women. Female Enterprise and Urban Development in Northern England, 1760-1830 (Oxford: 2006).

Bergeron, Louis, "Omul de afaceri" [The Businessman] in Omul luminilor, ed. Michel Vovelle (Iași: 2000).

Bernstein, Lina, "Russian Eighteenth-Century Merchant Portraits in Words and in Oil", in The Slavic and East European Journal, 3 (2005), 407-429.

Casson, Mark and Catherine, The Entrepreneur in History. From Medieval Merchant to Modern Business Leader (Basingstoke: 2013).

Cernovodeanu, Paul and Irina Gavrilă (eds.), Arhondologiile Țării Românești de la 1837 [The Wallachian Boyar Ledger from 1837] (Brăila: 2002).

Cernovodeanu, Paul and Nicolae Edroiu (eds.), Istoria Românilor [The History of Romanians]. Vol. vi (București: 2002).

Chirot, Daniel, Social Change in a Peripheral Society. The Creation of a Balkan Colony (London: 1976).

Cicanci, Olga, Companiile grecești din Transilvania și comerțul european în anii ${ }_{1636-1746}$ [Greek Companies in Transylvania and European Trade from 1636-1746] (București: 1981).

Craig, Béatrice, Women and Business since 1500: Invisible Presences in Europe and North America? (Basingstoke: 2016).

Crutzescu, Gh., Podul Mogoșoaiei: povestea unei străzi [Mogoșoaia’s Bridge: The Story of a Street] (București: 1986).

Davidova, Evguenia, Balkan Transitions to Modernity and Nation-States through the Eyes of Three Generations of Merchants (1780s-189os) (Leiden: 2013).

Drace-Francis, Alex, The Making of Modern Romanian Culture. Literacy and the Development of National Identity (London: 2006).

Fulga, Ligia and Lia, Maria, Voicu, Ceramica de tradiție habană: istorie, mentalități și relații comerciale în secolul al XVIII-lea [Haban-Tradition Ceramics: History, Mentalities and Trade Relations in the 18th Century] (Brașov: 2013).

Furnică, Dumitru Z., Din istoria comerțului la români, mai ales băcănia. Publicațiune de documente inedite: 1593-1844 [From the History of Commerce to the Romanians, Especially Groceries. Original Documents, 1593-1844] (București: 1908). 
Gelder, Maartje van, Trading Places. The Netherlandish Merchants in Early Modern Venice (Leiden: 2009).

Herlihy, Patricia, "Greek Merchants in Odessa in the Nineteenth Century", in Harvard Ukrainian Studies vol. 3/4, 1 (1979-1980), 399-420.

Iorga, Nicolae, Brașovul și românii. Scrisori și lămuriri [Brașov and the Romanians. Letters and Information] (București: 1905).

Jelavich, Barbara, History of the Balkans. Eighteenth and Nineteenth Centuries. Vol. I (Cambridge: 1983).

Kraus, Hans and L. Bachelin, Bucarest et la Roumanie, Bucarest: Socec, 1902.

Lahovari, Gheorghe I., Marele Dicționar Geografic al României [The Great Geographic Dictionary of Romania]. Vol. 2 (București: 1899).

Lazăr, Gheorghe, "Negustori mecena în Țara Românească" [Mecena Merchants in Wallachia] in Studii și Materiale de Istorie Medie, XXIII, 2005, 159-168.

Lazăr, Gheorghe, Les marchands en Valachie (XVII ${ }^{e}$ XVIII ${ }^{e}$ siècles) (București: 2006).

Livadă-Cadeschi, Ligia, De la milă la filantropie: instituții de asistare a săracilor din Țara Românească în secolul al XVIII-lea [From Pity to Philanthropy: Welfare Institutions for the Wallachian Poor in the 18th Century] (București: 2001).

Migden Socolow, Susan, The Merchants of Buenos Aires, 1778-1810. Family and Commerce (Cambridge: 1978).

Moașa Nazare, Ruxandra, Sub semnul lui Hermes și al lui Pallas. Educație și societate la negustorii ortodocși din Brașov și Sibiu la sfârșitul secolului al XVIII-lea și începutul secolului al XX-lea [Under the Hermes and Pallas Sign. Education and Society Among Orthodox merchants from Brasov and Sibiu from the End of the 18th Century to the Beginning of the 2oth century] (București: 2010).

Moring, Beatrice (ed.), Female Economic Strategies in the Modern World (London: 2012). Oțetea, Andrei, Pătrunderea comerțului românesc în circuitul international [The Emergence of Romanian Commerce in the International Market] (București: 1977). Papacostea, Șerban, Oltenia sub stăpânire austriacă (1718-1739) [Oltenia under Austrian rule (1718-1739)] (București: 1998).

Platon, Alexandru-Florin, Geneza burgheziei în Principatele Române (a doua jumătate a secolului al XVIII-lea - prima jumătate a secolului al XIX-lea): preliminariile unei istorii [The Emergence of the Bourgeoisie in the Romanian Principalities (Second Half of the 18th century to the First Half of the 19th Century)] (Iași: 1997).

Popica, Radu, "Portretele patriciatului săsesc din Brașov. Un capitol de arta transilvană" [Portraits of the Saxon Nobility of Brașov. A Chapter on Transylvanian Art] in Portretele Patriciatului Săsesc din Brașov. Un Capitol de Artă Transilvană. Catalog (Brașov: 2013).

Rabuzzi, Daniel A., "Women as Merchants in Eighteenth-Century Northern Germany: The Case of Stralsund, 1750-1830" in Central European History, 28, 4 (1995), 435-456. 
Roman, Nicoleta, “Ancien orphelin, futur citoyen de l'État. L'abandon infantile et l'assistance sociale entre initiative privée et autorité de l'État dans la Valachie moderne", in Silvia Marton and Constanța Vintilă-Ghițulescu (eds.), Penser le XIX'e siècle: nouveaux chantiers de recherche (Iași: 2013), 125-152.

Roman, Nicoleta, 'Deznnădăjduită muiere n-au fost ca mine'. Femei, onoare și păcat in Valahia secolului al XIX-lea ['There was No Other Woman as Hopeless as Me'. Women, Honour and Shame in 19th century Wallachia] (București: 2016).

Scriban, August, Dictionaru limbii românești [Dictionary of Romanian language] (Iași: 1939).

Simonton, Deborah, Women in European Culture and Society. Gender, Skill and Identity from 1700, (London: 2011).

Șăineanu, Lazăr, Dicționar universal al limbei române [Universal Dictionary of Romanian language] (Craiova: 1922).

Ulianova, Galina, Female Entrepreneurs in Nineteenth-Century Russia (London: 2009).

Vârtosu, Emil and Vârtosu, Ion, Așezămintele Brâncovenești. O sută de ani de la înfințare (1838-1938) [Brâncoveanu Establishments. A Hundred Years From Their Founding (1838-1938)] (București: 1938).

Vida, Mariana and Olariu, Elena, Epoca Biedermeier în Țările Române (1815-1859) [The Biedermeier Period in the Romanian Countries (1815-1859)] (București: 2014).

Vintilă-Ghițulescu, Constanța, "Să-mi ridic piatra de fată din casă". Strategii matrimoniale și conflicte familiale în societatea românească (secolul al XVIII-lea)." [Matrimonial Strategies and Familial Conflicts in Romanian Society (18th Century)] in Sorina Paula Bolovan, Ioan Bolovan and Corneliu Pădurean (eds.), Om și societate. Studii de istoria populației României (sec. XVII-XX), 95-105 (Cluj-Napoca: 2007).

Vintilă-Ghițulescu, Constanța, În șalvari și cu ișlic. Biserică, sexualitate, căsătorie și divorț în Țara Românească a secolului alXVIII-lea [In shalvari and with islic. Church, Sexuality, Marriage and Divorce in 18th-Century Wallachia] (București: 2011).

Zarinebaf, Fariba. "From Mahalle (Neighborhood) to the Market and Courts: Women, Credit and Property in Eighteenth Century Istanbul", in Jutta Gisela Sperling and Shona Kelly Wray (eds.), Across the Religious Divide. Women, Property and Law in the Wider Mediterranean (ca.1300-180o) (New York: 2010). 